\title{
Erratum to: The origins and early years of the American Society of Nuclear Cardiology
}

Frans J. Th. Wackers, ${ }^{a}$ and Jeffrey A. Leppo ${ }^{b}$

\section{ERRATUM TO: J NUCL CARDIOL DOI 10.1007/S12350-012-9651-5}

The last name of James A. Arrighi was misspelled in Table 3. The correct spelling is as shown in this erratum.

From the Department of Internal Medicine, Section of Cardiovascular Medicine, ${ }^{\text {a }}$ Yale University, New Haven, CT; and Department of Cardiology, ${ }^{\text {b }}$ Berkshire Medical Center, Pittsfield, MA

The online version of the original article can be found under doi: 10.1007/s12350-012-9651-5.

Reprint requests: Frans J. Th. Wackers, Department of Internal Medicine, Section of Cardiovascular Medicine, Yale University, New Haven, CT; frans.wackers@yale.edu.

J Nucl Cardiol 2013;20:172.

$1071-3581 / \$ 34.00$

Copyright (C) 2012 American Society of Nuclear Cardiology.

doi:10.1007/s12350-012-9665-z 